\title{
Teachers' perceptions of incorporation of corpus-based approach in English language teaching classrooms in Karachi, Pakistan
}

\author{
Javeria Jamal $^{1}$ | Asmara Shafqat*1 ${ }^{*}$ Ehtsham Afzal ${ }^{2}$
}

1. Department of Humanities, NED University of Engineering \& Technology, Karachi, Pakistan.

2. Department of Applied Linguistics, Awang Had Salleh Graduate School of Arts and Science, Kedah, University of Utara, Malaysia.

*Correspondence Emails: asmara.tayyeb@gmail.com | asmarashafqat@neduet.edu.pk

\begin{abstract}
The objective of the study is to understand language teachers' perceptions regarding incorporating a corpus-based approach, i.e., corpusbased teaching methodology in English Language Teaching (ELT) classroom contexts. The design of the study is qualitative. The sample is taken from 19 English language teachers who are currently enrolled as students of Master of Applied Linguistics at NED University, Karachi, Pakistan. The instrument of the study is an open-ended questionnaire and also a focus groups based on semi-structured interviews. A thematic analysis of the interviews is conducted, as a result of which different themes emerged that conform to the benefits of incorporating corpus-based materials and activities in ELT classrooms. The findings show that use of a corpus-based teaching methodology in ELT classrooms is accepted as a new strategy for teaching different aspects and skills of English language such as vocabulary, grammar, reading, and writing. The pedagogical implications are found to be significant for curriculum designers, ELT teachers, and administrators at educational institutes where they want to enhance their students' interest and motivation levels. Material designers, corpus-based tools researchers, and teachers are suggested to collaborate for designing effective corpus-based materials for teaching as it increases the reliability of the teaching material.
\end{abstract}

\section{Article History}

Received:

April 8, 2021

Last Revised:

June 21, 2021

Accepted:

June 23, 2021

Published:

June 30, 2021

Keywords: English language teaching, linguistic corpus, corpus linguistics, corpus-based approach, corpus based methodology, corpus-based materials, teachers' perceptions.

How to Cite: Jamal, J., Shafqat A. \& Afzal, E. (2021). Teachers' perceptions of incorporation of corpus-based approach in English language teaching classrooms in Karachi, Pakistan. Liberal Arts and Social Sciences International Journal (LASSIJ), 5(1), 611-629. https://doi.org/10.47264/idea.lassij/5.1.40

Publisher's Note: IDEA PUBLISHERS (IDEA Journals Group) stands neutral with regard to the jurisdictional claims in the published maps and the institutional affiliations.

Copyright: (C) 2021 The Author(s), published by IDEA PUBLISHERS (IDEA Journals Group). This is an Open Access article published under the Creative Commons Attribution-NonCommercial 4.0 International License (http://creativecommons.org/licenses/by-nc/4.0/) 


\section{Introduction}

Corpus linguistics can be defined as a field that is based on the use of authentic speech or text to explain the use of a specific linguistic concept, and therefore it is regarded as an approach to second and foreign language learning. Concept of a linguistic corpus became known in language teaching circles in 1987 with the introduction of first corpus-based dictionary for learners, i.e., Collins COBIULD English language dictionary, and research emphasizing the use of corpus-based materials in language classrooms. This sparked the interest in researching corpus-based language teaching (Boldarine \& Rosa, 2019; Chao, 2010; Romer, 2006). The emergence of a linguistic corpus concept has caused a significant shift in the methodology and philosophy of the English language teaching and learning (Binkai, 2012). A linguistic corpus can be defined as a collection or a database of authentic language in an electronic form. It can be accessed via the internet or software in the form of written or spoken texts.

Advancement in computer sciences has transformed the outlook towards language teaching. The most notable influence of computer sciences on language teaching and learning is corpus linguistics in designing, managing, and evaluating language corpora through computer systems (Yunus, 2017). Corpus linguistics is an electronic-based teaching methodology that can be very effective in ELT classroom contexts. Corpus linguistics can also be defined as a field based on authentic speech or text to explain the use of a specific linguistic concept (Reppen, 2010; Friginal, 2018). A linguistic corpus is employed to examine various language phenomena, historical and stylistic practices of language, second language acquisition, grammatical structures, discourse patterns, analyses, and is also helpful for classroom language pedagogy (Almutairi, 2016). In order to understand the efficacy of corpus linguistics as a teaching method or approach, many studies have been conducted to investigate how some language forms, expressions and vocabulary items are used by native speakers of English (Anthony, 2017).

It is overwhelming for language teachers of the $21^{\text {st }}$ century to improve their teaching and to find innovative ways to incorporate in their ELT classrooms as there is an array of various teaching materials such as printed materials, mobile applications and websites to offer both online and offline options for students to learn and use target language. Therefore, the decisions that language teachers make are complicated and involve different challenges such as students' needs, syllabus and curriculum design, preparation for conducting a lecture, and overall organization of a classroom. Among all the challenges that a teacher faces, learning and incorporating an innovative approach to language learning and teaching, such as a corpusbased approach is a difficult decision (Burns \& Richards, 2009). Hence, the current study strives to facilitate English language teachers and students to understand and incorporate a corpus-based approach in ELT classrooms. The study is beneficial not only for teacher and students regarding their decision-making to incorporate corpus-based materials in their classrooms but also helps administrators and policy makers at an educational institute to implement this approach as a language teaching methodology in their ELT classrooms.

\subsection{Categories and benefits of a linguistic corpus}

From a teaching approach, we can categorize a linguistic corpus as a general or specialized corpus. A general corpus can be used for understanding the global use of vocabulary items or phrases and can be further used for compiling a dictionary, whereas a specialized corpus is based on the spoken, or written language preferred for specific purposes. A specialized corpus 
is remarkably useful for identifying how language functions in a specific domain of language use. Therefore, for teaching a course such as English for specific purposes, using a specialized corpus is very useful (Donesch-Jezo, 2013).

There are different types of linguistic corpora for various reasons. A large corpus helps prepare a dictionary. It may contain billions of words, for the use of a dictionary involves many examples of all the words and expressions of a language. Corpora can also be categorized as spoken or written, parallel and learner corpus. A written corpus is designed from books, magazines or newspapers in electronic version. It may also be based on transcripts from literature. This type of corpus helps demonstrate the functions of a specific language in society. It is also helpful in explaining the changes that occur to a language with the passage of time and the different registers of the same language used in different regions by its inhabitants. A parallel corpus can be monolingual and bilingual. It has a source-text, and it is based on translations. It is beneficial in understanding languages' comparison. It is essential to understand and raise awareness of cultural differences with the use of parallel corpora. They are equally helpful for language teaching (Carter \& McCarthy, 2015). According to Newman (2008), spoken corpora are used to understand language functions in real-life situations. The spoken corpus is based on recordings of conversations of phone calls, conversations at the workplace and homes, TV shows and business meetings.

\subsection{Pedagogical benefits of corpus-based materials}

There are various pedagogical benefits of using corpus-based materials in ELT classrooms. The idea of using language materials based on databases or corpora expose our learners to the use of authentic language. Teachers use corpus linguistics as a source for teaching materials to facilitate learners in their ELT classrooms (O'Keeffe et al., 2007). The traditional way of using dictionaries for looking up definitions, meanings, and uses of a word to enhance our vocabulary is often very strenuous and time-consuming. However, with the help of the concordance tool of corpora, language learners are at an advantage of improving their language learning experience.

A linguistic corpus can be used by a learner, teacher, or researcher. Moreover, it is equally helpful for native speakers to enhance their lexical knowledge and improve academic writing. A linguistic corpus allows learners to be familiar with the target language in a practical way. A linguistic corpus is very efficient in planning and designing materials and exercises that make language teaching fundamental in classrooms (Hereman \& Cuyckens, 2012). Corpus is a valuable tool in teaching and learning vocabulary. It offers valuable information for both teachers and learners regarding language in real-life contexts (Römer, 2006). The corpusbased methodology has many advantages for teachers. Teachers know how to control the use of language teaching materials. Teachers can decide on how to expose their learners to the corpus relevant to them. In order to discuss words, collocations and help students understand the patterns of language use, teachers can use concordances (Reppen, 2011). In conventional vocabulary learning classrooms, teachers usually ask learners to memorize the word lists shared by the teachers and therefore their vocabulary learning remains inactive as they often tend to forget the words.

In contrast, by incorporating the corpus-based materials, teachers allow the learners to take part in an active vocabulary learning experience where they take charge of their learning with the help of language corpora. They explore the possibilities of language use in different 
situations (Gilquin \& Granger, 2010). This approach is also known as the data-driven learning, where the learners choose, determine and explore the forms of a word based on different technology-based resources. A corpus enables the individuals to explore how the language is used in the real-life situations, and therefore there remains no need to rely on a native speaker's idea of the language constructions, vocabulary, or expressions that are commonly or rarely used in English (Flowerdew, 2009). It is the concordance through which the information is examined. A concordance software enables an individual to indicate a word search to produce the concordance lines that further demonstrate all the occurrences of a given structure or a word present in a linguistic database and a context shared on each side of the occurrences (Timmis, 2015).

\subsection{Significance of the study}

Woods (1996) suggests that teachers' perceptions regarding their teaching methodology inform their attitudes and decisions in classrooms. Therefore, the study aims to explore teachers' perceptions of the incorporation of corpus-based approach i.e., different corpusbased materials, activities, and tools to facilitate teaching and learning in language classrooms. The analysis of teachers' perceptions is significant for two main reasons. Firstly, it allows us to understand how Pakistan teachers and students can use corpus-based materials and tools for teaching and learning English language learning. Secondly, the analysis of teachers' perception will help language teachers to make informed decisions regarding the incorporation of a corpus-based approach to their ELT classrooms. It is also hoped that the results of this study will help us understand if teachers consider corpus-based approach as a useful teaching methodology or only a replacement to already existing printed materials for language teaching and learning.

\section{Literature review}

Students taught using corpus-based materials can employ linguistic features in academic writing (Huang, 2014). Their positive attitude towards the use of corpus linguistics for language learning is also reflected in their actual language use with better use of collocations (Rezaee et al., 2014), vocabulary retention (Jalilifar et al., 2014), correct use of grammar rules (Smart, 2014), and ability to identify and revise linguistic errors when using a corpus (Tono et al., 2014). Studies in corpus linguistics from students' perspectives reveal their attitude towards corpus-based materials for learning a second or foreign language, in the same way, it is important to understand teachers' perceptions of the use of corpus-based materials and activities in ELT classrooms. Heather and Helt (2011) found different areas where teachers reported corpus tools as applicable. It helped classify students' errors and develop authentic teaching materials. The participants identified some limitations and difficulty working with corpus tools and the time required for analyzing the data. According to a survey study conducted by Mukherjee (2004), 248 schoolteachers admitted that they had never heard of a linguistic corpus, supporting the idea that much needed to be done for a linguistic corpus to be used by language teachers (Boulton, 2009; Frankenberg-Garcia, 2014; Gilquin \& Granger, 2010). Conrad (2008) deduced in research regarding the benefits of corpus tools in the context of L2 writing that corpus analysis offers teachers to handle flawed intuitions by using authentic language. According to Hunston (1995), it is essential to understand that incorporating corpus in language classrooms may expand the knowledge of language among teachers. It can also help teachers to evaluate their language awareness. 
According to Romer (2005) it is essential to establish a base for developing corpus-based language materials that demonstrate actual language use. The use of corpus-based materials as proposed by (Aston, 2001; Sinclair, 2004; Bennet, 2010; Reppen, 2010) can be encouraged in ELT classrooms to utilize corpus and make the most of it for themselves as well as for their students. Ashkan and Seyyedrezaei (2016) conducted a quasi-experimental study to investigate the effect of corpus-based teaching methodology on Iranian EFL learners' vocabulary and retention. The study participants were taught corpus-based approaches in the experimental group compared to students in the control group who were taught traditional methods. A pretest was conducted before instruction, and later a posttest was conducted. In order to examine retention of vocabulary after being taught by corpus-based approach, a second posttest was administered to both groups after two weeks of the first posttest. The study results showed that there was a significant effect on EFL learners' vocabulary and retention. Çaliskan and Gönen (2018) conducted a study to offer training on designing and integrating corpus-based materials in vocabulary teaching and surveyed teachers' perceptions about using the same materials in their classrooms. The participants of the study were three EFL instructors from a Turkish state university. The data collection instruments included reflective logs, semi-structured interview and open-ended questionnaires. The study's findings revealed that EFL university instructors had no prior awareness regarding the use of corpusbased materials in vocabulary instruction. They perceived the use of corpus-based materials as advantageous for teaching vocabulary.

The research conducted about the educational situation in Pakistan suggest that there is a severe need for educational reform through changing traditional and incompetent model of second and foreign language learning. The reason for our students' weak performance is the use of an ineffective pedagogical approach (Haider, 2012; Durrani, 2016). Research conducted by Imran et al. (2016) at public colleges of Pakistan revealed that intermediate college students find it challenging to distinguish significant word classes, i.e., noun and verb. Another study conducted at Lasbela University infers that the students tend to feel anxiety given English language learning opportunities due to the lack of prior exposure to the language (Gopang et al., 2017).

A study conducted by Farooq et al. (2012) deduced that second and foreign language learners of English in Pakistan assume that the main problem they face regarding learning English is their thought process where they tend to think first in their mother tongue or first language and then translate it into the English language. The study found that the most frequent problems these students face included L1 interference and lack of vocabulary. The study also revealed that the reason behind these problems was the prevalent use of the grammar-translation method for teaching English in most parts of the country. Therefore, teachers in Pakistan need to incorporate modern methods in ELT classrooms such as corpus-based teaching methodology. In Pakistan, most of the studies conducted in the domain of corpus linguistics are corpus-based analyses (Mahmood, 2009; Mushtaq et al., 2021; Afzal et al., 2019). Zahra and Abbas (2018) conducted a study where they employed the Michigan Corpus of Academic Spoken English (MICASE) for understanding the pedagogical implications and uses of a linguistic corpus in the context of ELT in Pakistan.

The awareness of the teachers about the corpus-based approach helps them in their decision making regarding different corpus-based materials e.g., software and tools (Özbay \& Kayaoğlu, 2015). There is minimal published literature available on teachers' perception of the corpus-based approach for teaching and learning the English language in Pakistan. Therefore, 
it is significant to understand teachers' perceptions of the incorporation of corpus-based methodology in ELT classrooms in a Pakistani context to facilitate ELT community making informed decisions to improve language pedagogy.

\section{Theoretical foundation}

The present study utilizes the corpus approach as a basis for its theoretical foundation. According to Bennet (2010), Flowerdew (2009) and Stefanowitsch (2020) it is a method that is used for analyzing, teaching, and learning a second and foreign language. According to Biber et al. (1998), the corpus approach is based on four characteristics i.e., it is empirical in nature, uses a large collection of natural texts, uses computers and software extensively, and employs both quantitative and qualitative techniques. These characteristics establish the corpus approach as a suitable framework for the current study. The participant teachers of the study use different corpus-based software and tools to design teaching materials and incorporated these materials in their ELT classrooms. The study uses both quantitative and qualitative data to analyze teachers' demographics and their perceptions of the incorporation of a corpus-based approach in their ELT classrooms.

\section{Research methodology}

The design of this research study is a qualitative survey. This research aims to have a holistic understanding of teachers' perceptions of the corpus-based approach for teaching in ELT classrooms. To develop a better and in-depth understanding of the use of the corpus-based approach in ELT classrooms, the researchers have used two different data collection tools; questionnaire and focus group interviews, for maintaining the reliability and validity of the research. The objective of the research is to understand teachers' perceptions regarding the incorporation of corpus-based methodology in ELT classrooms. The study question is what are the teachers' perceptions regarding the incorporation of corpus-based methodology in ELT classrooms? The research site is NED University of Engineering and Technology, located in the urban area of Karachi, Pakistan. It is an HEC and PEC certified university offering the undergraduate programs leading to graduate programs of $\mathrm{MS}$ and $\mathrm{PhD}$. The participants are both males and females. There are 19 participants in the study.

\subsection{The procedure of the research}

An email invitation was sent to participants. The research data was gathered after the informed consent of survey respondents. Seven respondents who showed their interest in semistructured interviews were invited for focus group interviews. The researchers have used two different methods of data collection. First, a questionnaire is used to ascertain the significance of corpus-based methodology for teachers and how they incorporate these corpus-based materials and activities to teach the English language in their classrooms. Then, the researchers conducted detailed follow-up interviews to understand teachers' perception about the incorporation of the corpus-based methodology in ELT classrooms. The qualitative data analysis technique used in the study is thematic analysis to create meaningful patterns emerging from participants' experiences using English language corpus in ELT classrooms.

\subsection{Data collection instruments}

An online questionnaire was sent to 19 participants via emails. A sub-section of respondents 
was selected to participate in a focus group interview. It was a follow-up semi-structured interview to develop a better and in-depth understanding of how teachers perceive corpusbased methodology in the ELT classrooms.

\subsubsection{Questionnaires}

The purpose of the questionnaire was to collect data about teachers' experiences using the corpus-based methodology in ELT classrooms. The researcher developed the questionnaire online using google forms by adapting a quantitative questionnaire from a study based on a similar topic (Bunting, 2013). The questionnaire is based on three parts. In the first part, the participants provided some demographic information. In the second part, the participants responded to questions regarding their use of the corpus-based methodology for English language teaching. In the third part, they responded to questions regarding the significance of corpus-based materials and activities for English language teaching inside classrooms.

\subsubsection{Interviews}

The purpose of the follow-up interviews was to gather an in-depth data on teachers' experiences of incorporating corpus-based methodology and using corpus-based materials and activities in their ELT classrooms. The focus group interviews were based on two parts discussed below. The purpose of the first part was to determine the participants' understanding of their experiences of corpus-based teaching methodology. The purpose for the second part of the interview was to explore whether and how the participants' teaching experiences have changed after the incorporation of corpus-based materials and activities for teaching different aspects and skills of the English language such as vocabulary, grammar, reading, and writing.

\section{Data analysis}

Two different methods were used for data analysis. The questionnaires were analyzed with the help of tables, pie charts, and clustered bar charts using MS Excel to visually calculate percentages and present data. In contrast, the semi-structured focus group interviews were first to voice recorded, reproduced into transcriptions, and analyzed thematically.

\subsection{Analysis of the questionnaire: Quantitative data}

Section 1 of the questionnaire was based on five items concerning age, gender, the first language of participant teachers, and their institutes' regions. Item 1 is a question based on the gender of the teachers (participants). As shown in figure 1, of all 19 participants, $73.3 \%$ are females, and $26.3 \%$ are males, which confirms that very few males opt for teaching English language teaching in Pakistan.

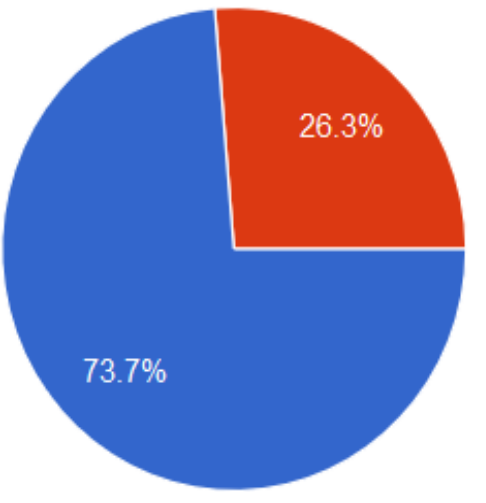

Figure 1: Gender of the teachers 
Item 2 of the questionnaire is about the age of the participant teachers. It is evident from figure 2 , that $47.4 \%$ of the teachers belong to the age ranging from 20 to 29 years, $42.1 \%$ belong to the age ranging from 30 to 39 , and only $10.5 \%$ belong to the age range from 40 to 49 years. This shows that most participants are millennials (22-37 years old) who stand out for their ease of technology use in the $21^{\text {st }}$ century.

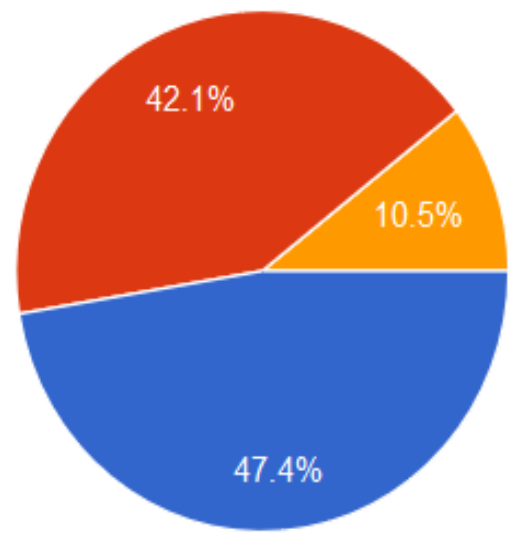

Figure 2: Age of the participant teachers

Item 3 is about the linguistic background of the participant teachers, and from the figure 3 , it is clear that the first language of $63 \%$ of the participant teachers is Urdu. Moreover, both the Punjabi and Balochi are spoken by $11 \%$ of the participant teachers, respectively. The other three languages, i.e., Brushaski, Saraiki and Sindhi, and Urdu are the first languages of 5\% of the participant teachers.

Figure 3: The first language of the participant teachers

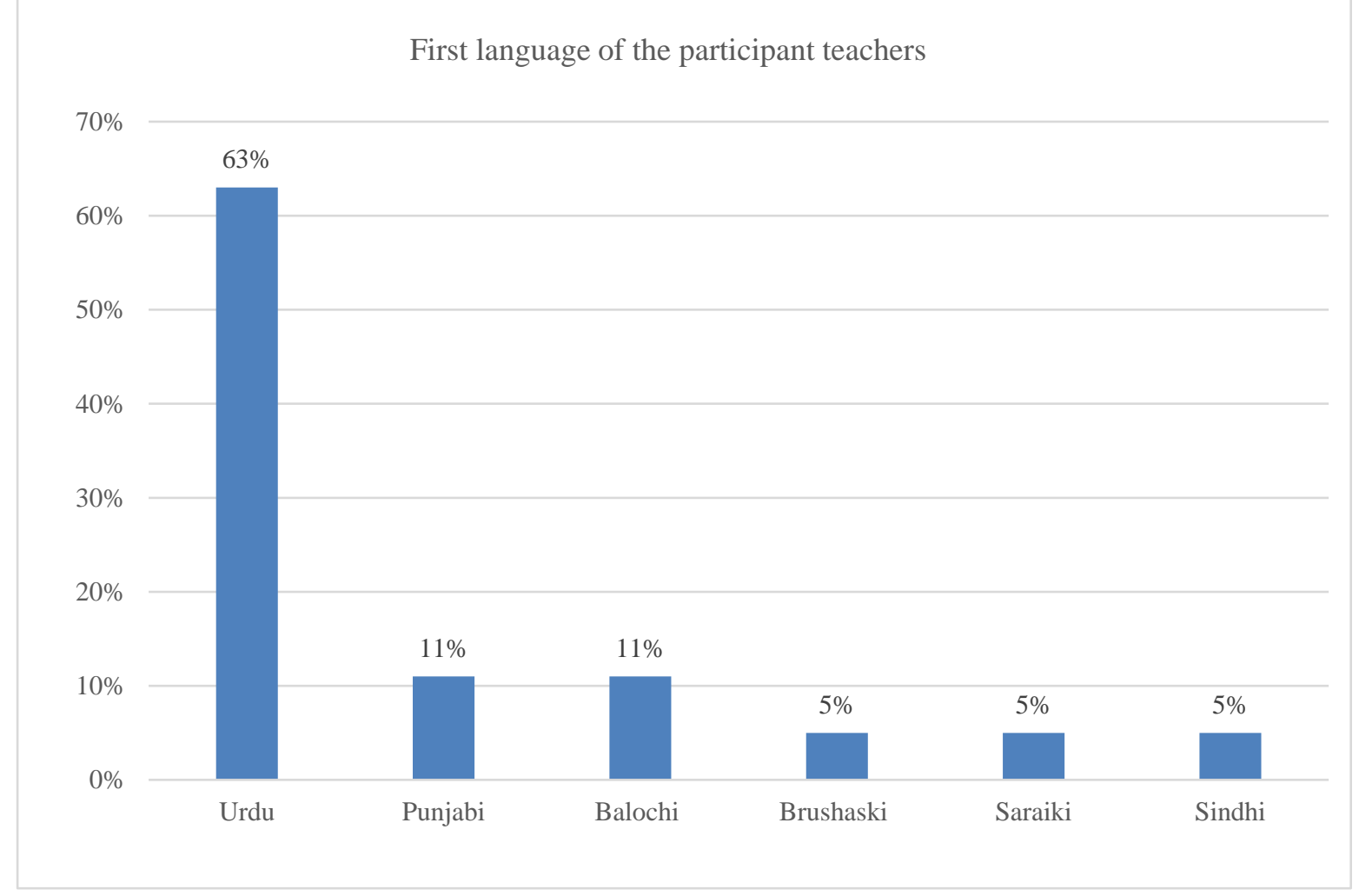

Item 4 asked the teachers about the name of the institutes where they are teaching. In order to maintain the privacy and confidentiality of the participant teachers, the institutes were categorized into two regions of Sindh; Urban Karachi and Larkana. 95\% of teachers teach at institutes based in Urban Karachi, Sindh, and 5\% of teachers teach at institutes based in Larkana, Sindh. 
Figure 4: Regions of teachers' institutes

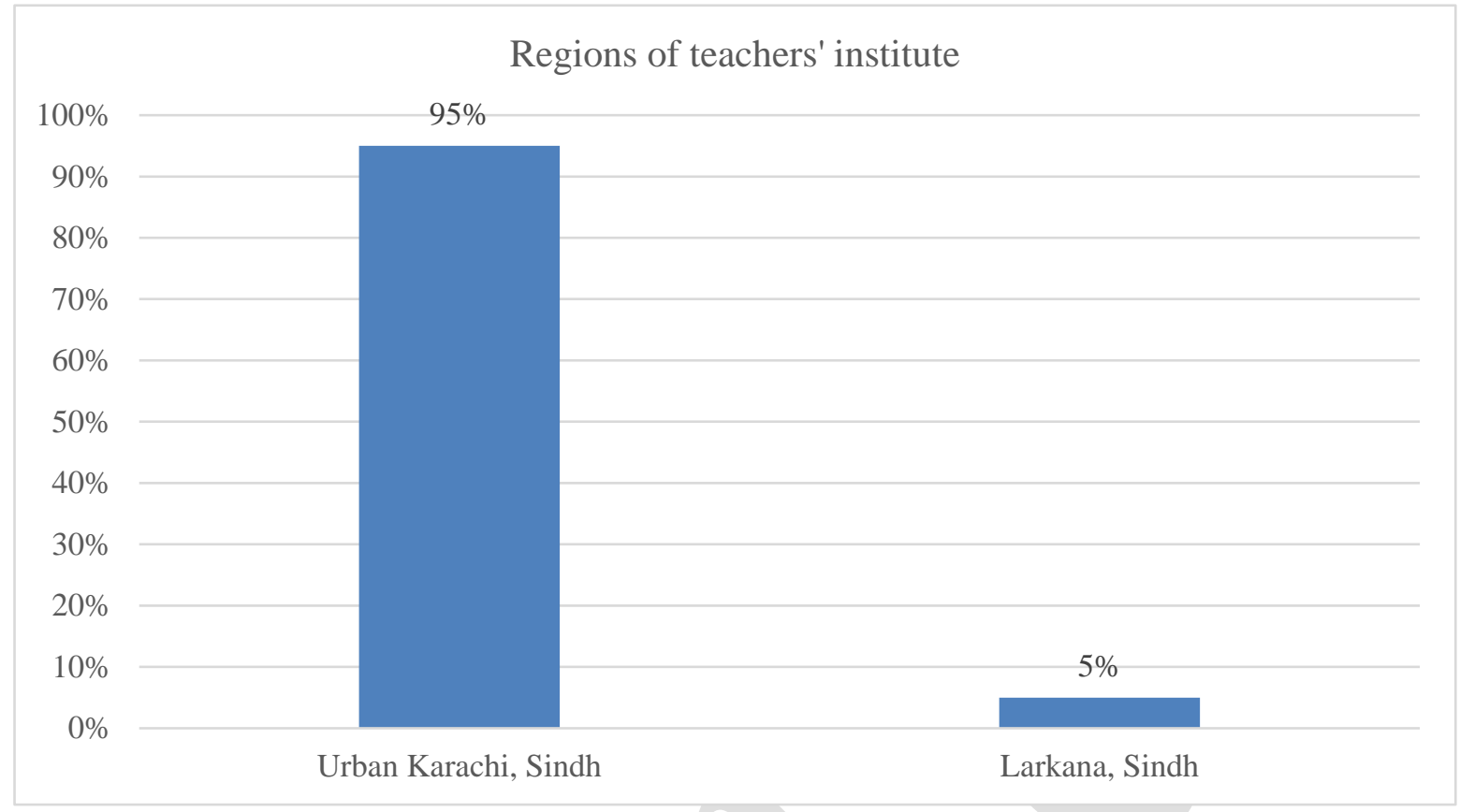

Item 5 was about the different levels that the teachers have experience of teaching. It is evident in figure 5 that $42 \%$ of teachers taught students of upper-intermediate level, $23 \%$ of teachers taught intermediate level of students, $20 \%$ of teachers taught advanced level of students. In contrast, only $15 \%$ of teachers were involved in teaching pre- intermediate levels that can also be categorized as proficient. The advanced level can be defined as master's level and undergraduate level.

Figure 5: Language teaching experience in terms of levels

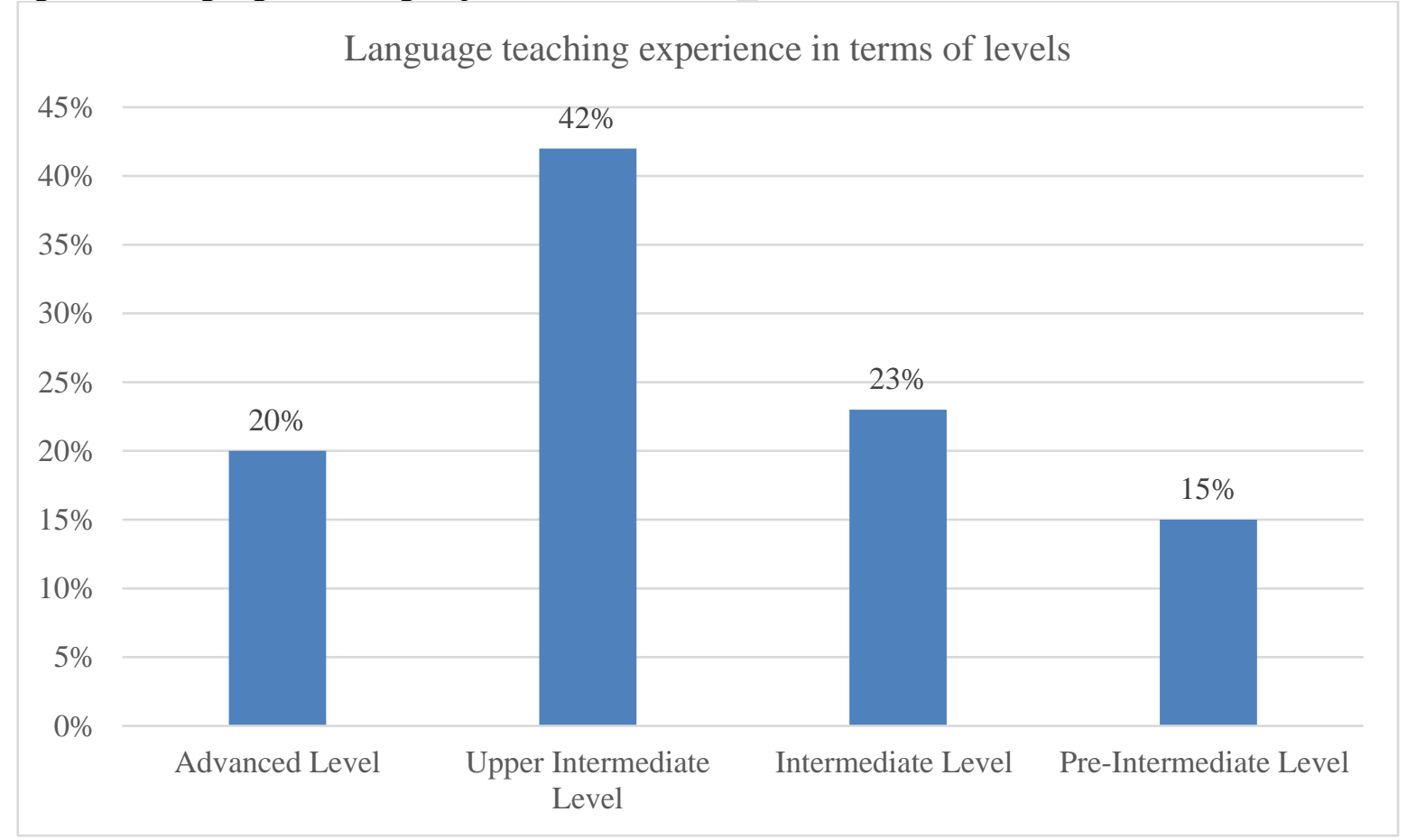


the item 6 was simply a "yes" or "no" question about the participant teachers' experience of using the corpus-based methodology in their language classrooms. Of the total, $73.7 \%$ of participant teachers used corpus in their language classrooms whereas only $26.3 \%$ of participant teachers did not use the corpus in their classrooms.

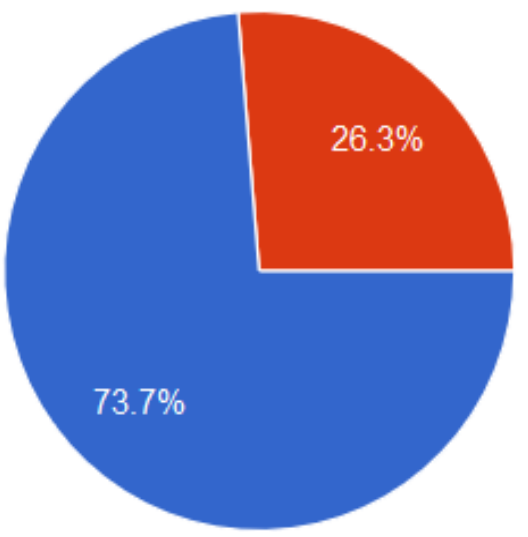

Figure 6: Teachers' experience of corpus-based methodology

Item 7 was designed to understand the different skills/areas of language that the participant teachers have used corpus for teaching in their language classes. 33\% of teachers used corpus for teaching grammar, $28 \%$ of teachers used it for their writing classes, $17 \%$ used it for vocabulary classes, and $11 \%$ of teachers used it for reading, and $11 \%$ of teachers used corpus for other skills.

Figure 7: Use of corpus-based methodology for different skills and aspects of English

Use of Corpus-based methodology for different skills and aspects of English

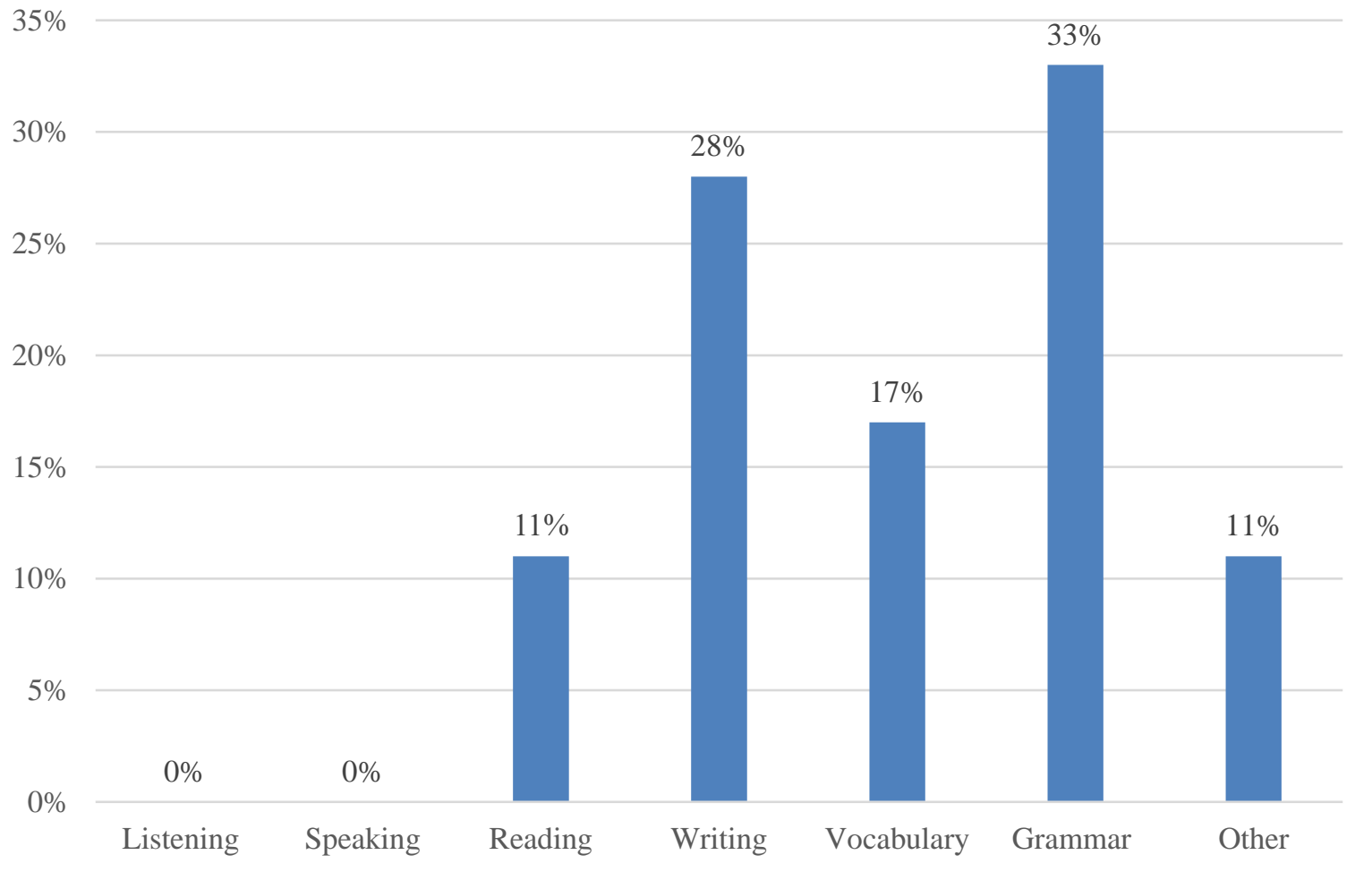

Item 8 asked the participant teachers about using different tools and software for designing their corpus-based materials. This item had 17 responses where $46 \%$ used AntConc, $36 \%$ of teachers used both AntConc and TagAnt. Google and Sketch Engine were used by $9 \%$ of teachers respectively. 
Figure 8: Corpus-based tools and Software

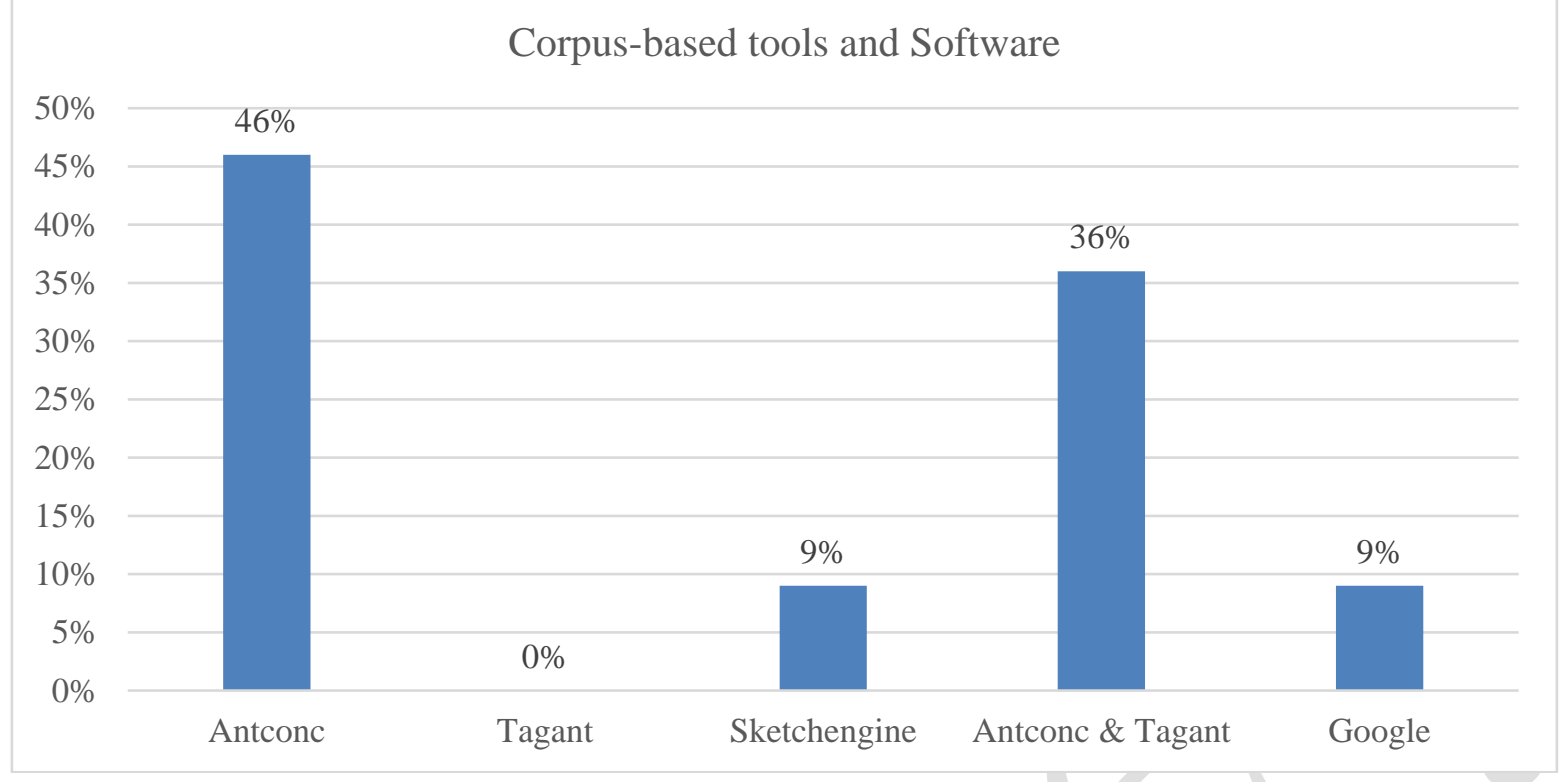

Item number 9, aimed at understanding teachers' reasons behind their incorporation of the corpus in their language classrooms. According to $26 \%$ of teachers, corpus linguistics is practical for language teaching and learning, $21 \%$ of teachers said that it improved their students' vocabulary, $16 \%$ of teachers said that it helped design insightful lessons, $11 \%$ of teachers said it was the source of real-life language. For $11 \%$ of teachers, there were other advantages of using corpus in their classrooms respectively, $5 \%$ of teachers said it promotes a sense of independent learning, motivates students and enhances students' interest.

Figure 9: Reasons for using corpus in language classrooms

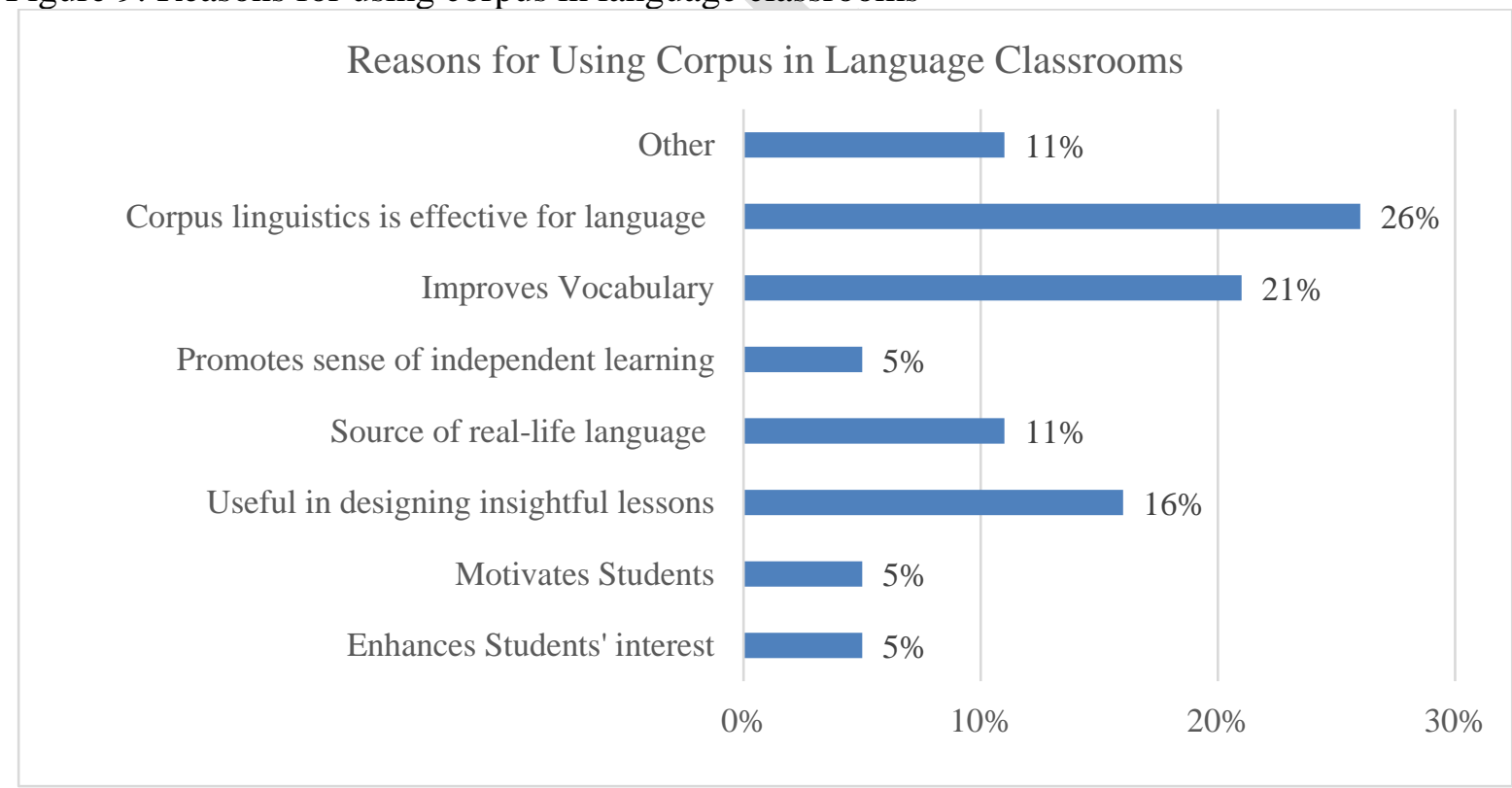

Item 10, the statement "Using corpus-based tools/software improve your students' learning" was used to test teachers' perceptions regarding the use of corpus for teaching different areas and skills of the English language. 53\% of teachers perceive corpus-based tools as effective for improving their students' grammar, $26 \%$ thought it improved their students' vocabulary, 
$16 \%$ of teachers considered the use of corpus-based tools to improve their students' writing skills. In contrast, only $5 \%$ of teachers thought that corpus tools improved the reading skills of their students.

Figure 10: Skills and aspects that corpus improves

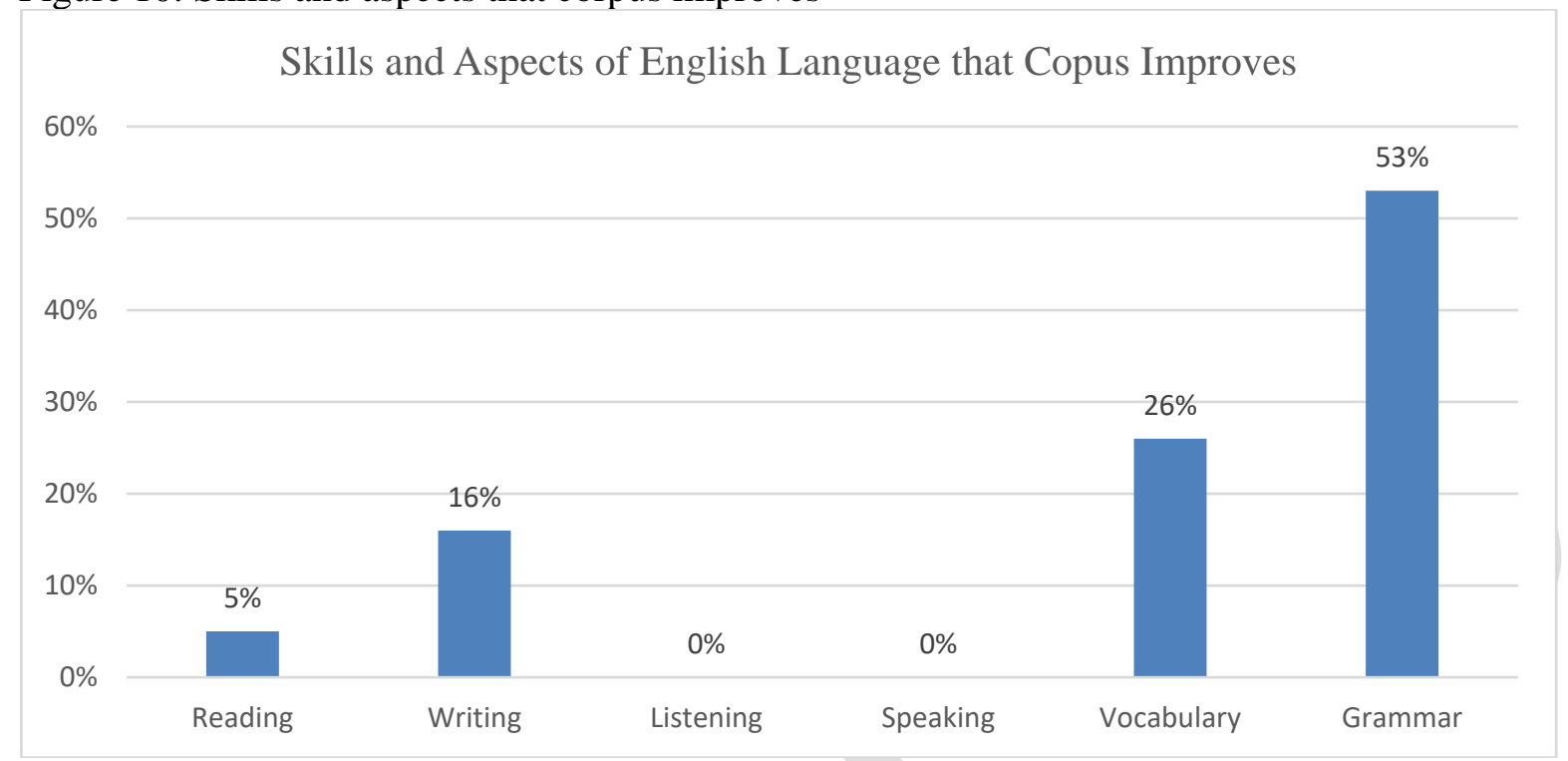

Item 11 asked the students about the most helpful topics in classroom teaching. As figure 11 shows, that it is a check that applies question. According to $26 \%$ of teachers surveyed found corpus-based tools helpful in teaching vocabulary in their classrooms, $21 \%$ of teachers found it useful for teaching grammar, $16 \%$ of surveyed teachers found that learning about how to use a corpus and how to create a corpus is equally crucial for classroom teaching. $11 \%$ of teachers directly used the corpus with their students, and only $5 \%$ of them used it for teaching writing skills and to create teaching materials for EFL / ESL classrooms.

Figure 11: The most helpful topic in classroom teaching

\section{The most helpful topics in ELT classrooms}

Using Corpus-based tools to improve vocabulary

Using Corpus-based tools to improve grammar

Creating a corpus

Learning about and using corpus softwares programs such AntConc

Analyzing and using concordance lines to create teaching materials

Using corpus-based tools to improve writing

Using corpus tools directly with students

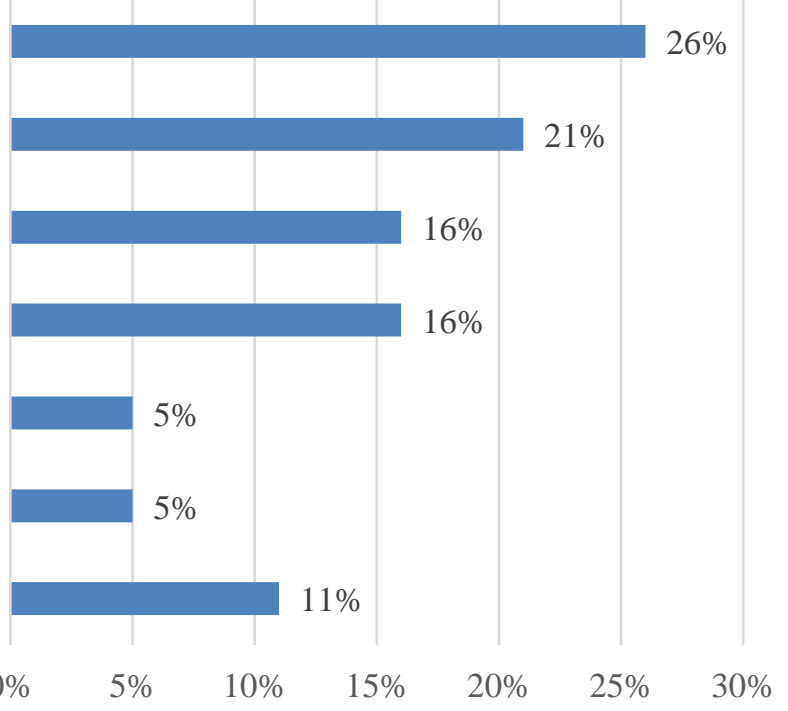




\subsection{Analysis of focus group interviews: Qualitative data}

Focus group interviews were analyzed after coding the transcriptions. As a result, different themes emerged inductively.

Table-1: Teachers perceptions on incorporation of corpus-based methodology in ELT classrooms

\begin{tabular}{|l|l|l|}
\hline Themes & \multicolumn{2}{|l|}{ Perceptions } \\
\hline $\begin{array}{l}\text { Corpus-based } \\
\text { methodology supports } \\
\text { language teaching. }\end{array}$ & - It helps in identifying and rectifying basic mistakes of students in \\
their use of vocabulary and grammatical structures.
\end{tabular}

The interview consisted of four questions. The findings and analysis are as follow:

\subsubsection{What are the most effective ways, corpus can be used in your ELT classrooms?}

Teachers reported that they used two software AntConc and TagAnt for designing their corpus, activities for teaching grammar and vocabulary. AntConc could find word frequency and uses of a word in different contexts, whereas TagAnt helped them tag different parts of the speech. Both of these software proved helpful in designing relevant and specific activities. The use of corpus-based software made teaching and learning innovative and accessible. One participant (P1) shared her experience of incorporating corpus tools as: "We also designed many activities that were used for teaching that difficult vocabulary and phrasal verbs in a fun and innovative way." Another participant (P4) said, "The group that was taught with corpus, they did the activities much better, and they were more interested in using corpus and the group which was not taught with the corpus ending up saying that they really wanted to be taught with the incorporation of corpus." According to a participant (P5):

"With the help of this data we can improve our teaching, we come to know our learners' frequent errors, their weaknesses, strengths in language use, and 
likewise, we can bring changes in our teaching strategies. We can determine different areas of language we need to focus on. We can also analyze the written scripts of learners; their written errors can be identified, and their spoken errors can also be identified."

\subsubsection{Do you feel you achieved your goals for the class session?}

For this question, $100 \%$ of the interviewed teachers responded positively. They met their classrooms goals and were very happy with the effectiveness of the corpus in classrooms. Participant (P4) stated, "Yes, the goals met. I was sure that if I introduce corpora in my classrooms, there will be an improvement in learning English." Another interviewed teacher (P5) responded as, "I could easily tag all the vocabulary to their respective parts of speech. I made notes for teaching "parts of speech" and distributed them among my students."

\subsubsection{Do you think the students enjoyed the lesson?}

Analysis of this question suggested that the students were motivated to learn. As it was a new way of learning a language with the incorporation of corpus tools and activities, in the beginning, they learned and later, after understanding the use of corpus tools and activities, they even performed very well. These insights were shared by the participant teachers as (P7) shared, "Students' response was also good. They were happy with the idea of using this software." Furthermore, according to another participant (P5), "Learners were also happy to see innovation and technology in their language classrooms."

\subsubsection{What is the attitude of the administration of your program towards incorporating corpus-based methodology in ELT classrooms?}

Analysis of all the responses for this question suggests that the administration of the institutes appreciated them for using corpus-based materials, tools, and activities in language classrooms. Moreover, they provided the teachers with conditions conducive to the incorporation of the corpus in language classrooms. It is clear from the statements of the participant teachers as they affirmed that they experienced the positive attitude of their respective administrators. According to one of the participants (P2):

"They were very cooperative about it, and of course I belong to a university where they appreciate using the technology and particularly when it comes to teaching language students." (P3) said, "As teachers, we overcome all the barriers in teaching and learning so I had to approach the HOD and the department, and they adhered to me."

\section{Discussion and findings}

Findings from the semi-structured interviews validate the qualitative data gathered from the questionnaires. Interviewed teachers stated that they found many advantages of using corpusbased materials such as a list of parts of speech and concordance lines and activities in teaching different grammar, vocabulary, and writing in their ELT classrooms. They used corpus-based tools and software such as AntConc (Yusuf, 2020) and TagAnt to design materials for language teaching. Furthermore, teachers suggested that corpus-based software can be used to identify the basic mistakes that students make. This software can be used to 
rectify the mistakes in the basic structures and enhance students' vocabulary. TagAnt facilitates the students by providing them with word classes of every word in a given text. The students were surprised to discover that the AntConc software could provide the total number of nouns presented in a text.

It is believed that the incorporation of corpus-based methodology, materials, and exercises is beneficial for teachers. Such incorporation will allow teachers to impart an understanding of target words with the use of real-life texts. It will also promote opportunities for learners to collaborate in exploring various uses of a word. Teachers can integrate technology by using concordance lines from the corpus (COCA) and design different activities such as cloze tests, matching the appropriate meaning of the target words, and multiple-choice questions. The incorporation of technology makes teaching and learning more fun and keeps the teachers and learners motivated and active. It is equally important for teachers to guide learners on using a linguistic corpus as these students cannot solve their language learning problems independently; they would also find difficulty in adopting new technology in language learning (Yoon \& Hirvela, 2004).

\subsection{Pedagogical implications}

\subsubsection{Implications for corpus tools specialists}

The corpus tools that researchers may address are pedagogical practices of corpus-based research. They may belong to a teaching background. They should bridge the gap between the finding of corpus-based research and the needs of corpus for teaching and learning a foreign language.

\subsubsection{Implications for material designers}

According to Romer (2006), corpus researchers and textbook publishers can have a close collaboration. Material designers, corpus tools researchers, and teachers' educators should collaborate rather than directly approaching a teacher. This way, designing effective materials for teaching will be teamwork and increase the materials' reliability.

\subsubsection{Implications for teacher educators}

The teacher educators can offer the pre-service teachers a more comprehensive understanding of the corpus linguistics and the scope and purpose of the corpus-based materials and tools in corpus linguistics courses. In-service teachers, in the same way, should be offered more professional development opportunities based on the use of corpus-based materials and activities combined with technology integration, lesson planning and skill-centered workshops and training sessions.

\subsubsection{Implications for administrators}

The workplace conditions play a significant role in the teacher performance. Teachers should be given proper time for the research. It is the responsibility of the administrators to provide the teachers with the resources such as the language labs, technology, and support for professional development. 


\section{Conclusion}

The purpose of the study was to explore teachers' perceptions of the incorporation of corpusbased approach, i.e., corpus-based teaching methodology, to decide what different aspects of corpus-based tools and materials should be incorporated into Pakistani ELT classrooms. The present study's findings reveal that the use of corpus-based materials and activities for English language teaching and learning is very beneficial. A corpus-based approach to language teaching and learning encourages student-centered learning and offers learners to take their learning decisions. The study has also provided valuable insights into teachers' perceptions regarding incorporating corpus-based materials and activities for teaching grammar, vocabulary, reading and writing in their ELT classrooms. The data gathered from a qualitative survey and focus group interviews have made it evident that using corpus-based materials for English language teaching and learning is more effective than traditional teaching methods. It facilitates teachers and students with the use of authentic language. Corpus-based approach i.e., corpus-based teaching methodology, is an innovative way of teaching and learning English as it brings real-life situations into language classrooms (Yang, 2015). Teachers find it easy to design their corpus-based materials and activities using user-friendly software such as AntConc and TagAnt.

\subsection{Possible future research}

One possibility for future research is to investigate the development of corpus-based materials using different software and their implementation in varied contexts. Another possibility for future research is to investigate the effectiveness of corpus linguistics courses as part of language teacher education programs.

\section{References}

Afzal, M., Hu, K., Chishti, M.I., Khan, Z., \& Feng, G. (2019). Examining Pakistani news media discourses about China-Pakistan Economic Corridor: A corpus-based critical discourse analysis. Cogent Social Sciences, $\quad 5(1) . \quad$ 1-18. https://doi.org/10.1080/23311886.2019.1683940

Almutairi, N. (2016). The effectiveness of corpus- based approach to language description in creating corpus-based exercises to teach writing personal statements. English Language Teaching, 9(7). 103-111. https://eric.ed.gov/?id=EJ1101749

Anthony, L. (2017). Corpus linguistics and vocabulary: A commentary on four studies. Vocabulary Learning and Instruction, 6(2), 79-87 https://www.laurenceanthony.net/research/20171200_vli_article/VLI_6_2_anthon y.pdf

Ashkan, L., \& Seyyedrezaei, S.H. (2016). The effect of corpus-based language teaching on Iranian EFL learners' vocabulary learning and retention. International Journal of English Linguistics, 6(4).190-196. https://pdfs.semanticscholar.org/c0b8/76c33ecd602b88f3092ee974e16a98db7ee4.p $\underline{\mathrm{df}}$

Aston, G. (ed.) (2001). Learning with corpora. Athelstan.

Bennet, G. R. (2010). Part I: An introduction to corpus linguistics. University of Michigan. https://www.press.umich.edu/pdf/9780472033850-part1.pdf 
Biber, D., Conrad, S., \& Reppen, R. (1998). Corpus linguistics - investigating language structure and use. Cambridge University.

Binkai, J. (2012). An empirical study on corpus-driven English vocabulary learning in China. English Language Teaching, 5(4). 131-137. https://eric.ed.gov/?id=EJ1079027

Boldarine, A.C., \& Rosa, R.G. (2019). Prepping a prep course: A corpus linguistics approach. BELT- Brazilian English Language Teaching Journal, 9(2). 397-394. https://revistaseletronicas.pucrs.br/index.php/belt/article/view/31799

Boulton, A. (2009). Data-driven learning: Reasonable fears and rational reassurance. Indian Journal of Applied Linguistics 35(1), 81-106. https://hal.archives-ouvertes.fr/hal$\underline{00326990 /}$

Bunting, J. (2013). An investigation of language teachers' explorations of the use of corpus tools in the English for Academic Purposes (EAP) class. https://scholarworks.gsu.edu/alesl_diss/26

Burns, A., \& Richards, J. (2009). Second language teacher education. In A. Burns \& J. Richards (Eds.), Cambridge guide to second language teacher education. Cambridge University.

Caliskan, G., \& Gonen, S.İ. (2018). Training teachers on corpus-based language pedagogy: Perceptions on using concordance lines in vocabulary instruction. Journal of Language and Linguistic Studies, 14(4), 190-210. https://dergipark.org.tr/en/pub/jlls/issue/43366/528108

Carter, R., \& McCarthy, M. (2015). Spoken grammar: Where are we and where are we going? Applied Linguistics, 38(1).1-20. https://doi.org/10.1093/applin/amu080

Chao, P. (2010). A study of collocation learning of junior high students in Taiwan via concordance. Paper presented at the 2010 international conference on English teaching, Kaohsiung, Taiwan. 129-154 https://www.academia.edu/download/8652879/2010comp_epca.pdf\#page=139

Conrad, S. (2008). Corpus-based research is too complicated to be helpful in writing teachers. In J. Reid (Ed.), Writing myths: Applying second language research to classroom teaching. University of Michigan.

Donesch-Jezo, E. (2013). Using language corpus in teaching foreign language vocabulary. International Multidisciplinary e-Journal, 2(1), 11-25.

Durrani, H. (2016). Attitudes of undergraduates towards grammar translation method and communicative language teaching in EFL context: A case study of SBK women's university Quetta, Pakistan. Advances in Language and Literary Studies, 7(4), 167172. https://eric.ed.gov/?id=EJ1127286

Farooq, M. S., Uzair-Ul-Hassan, M. \& Wahid, S. (2012). Opinion of second language learners about writing difficulties in English language. A Research Journal of South Asian Studies, 27(1), 183-194. http://journals.pu.edu.pk/journals/index.php/IJSAS/article/view/2847

Frankenberg-Garcia, A. (2014). How language learners can benefit from corpora, or not. Recherches en didactique des langues et des cultures. 11(1), 1-15. https://doi.org/10.4000/rdlc.1702

Friginal, E. (2018). Corpus linguistics for English teachers: tools, online resources, and classroom activities. Routledge.

Flowerdew, L. (2009). Applying corpus linguistics to pedagogy: A critical evaluation. International journal of corpus linguistics, 14(3), 393-417. https://doi.org/10.1075/ijcl.14.3.05flo

Gilquin, G., \& S. Granger (2010). How can DDL be used in language teaching? In A. 
O'Keeffe \& M. McCarthy (eds.), The Routledge handbook of corpus linguistics. Routledge.

Gopang, I. B., Ansari, S., Kulsoom, U., \& Laghari, A. (2017). An empirical investigation of foreign language anxiety in Pakistani university. International Journal of English Linguistics, 7(2). 21-31.

Haider, G. (2012). Teaching of writing in Pakistan: A review of major pedagogical trends and issues in teaching of writing. Journal of Educational and Social Research, 2(3), 215-215.

Heather, J., \& Helt, M. (2011). Pre-service teachers' attitudes towards corpus use in [grammar] teaching. Paper presented at the American Association of Corpus Linguistics, Atlanta, GA.

Heremans, K., \& Cuyckens, H. (2012). DIACHRONEX: Corpus-based exercises for English diachronic linguistics. ICAME Journal, 36,

67-93. http://korpus.uib.no/icame/ij36/Pages_67-94.pdf

Huang, Z. (2014). The effects of paper-based DDL on the acquisition of lexico-grammatical patterns in $\quad$ L2 163-183. https://www.cambridge.org/core/journals/recall/article/abs/effects-of-paperbasedddl-on-the-acquisition-of-lexicogrammatical-patterns-in-12writing/F70DB438DA5EAB9F733103F7A1F3A47E

Hunston, S. (1995). Grammar in teacher education: The role of a corpus. Language Awareness, 4(1), 15-31. https://doi.org/10.1080/09658416.1995.9959864

Imran, M., Asgher, T., \& Ghani, M. (2016). A study on science students' understanding of three lemmas: State verb, action verb and noun in the state-run colleges in Pakistan. International Journal of English Linguistics, 6(5), 121-129. https://pdfs.semanticscholar.org/d3c0/926b88165c6288b4c93e549c1b276e0cec34. pdf

Jalilifar, A., Mehrabi, K., \& Mousavinia, S. R. (2014). The effect of concordance enriched instruction on the vocabulary learning and retention of Iranian EFL learners. Procedia-Social and Behavioral Sciences, 98, 742-746. https://doi.org/10.1016/j.sbspro.2014.03.476

Mahmood, M. A. (2009). A corpus-based analysis of Pakistani English. Bahauddin Zakariya University, Multan.

Mukherjee, J. (2004). Bridging the gap between applied corpus linguistics and the reality of English language teaching in Germany. In U. Connor \& T. Upton (Eds.), Applied corpus linguistics: A multidimensional perspective. Rodopi.

Mushtaq, M., Saleem, T., Afzal, S., \& Saleem, A. (2021). A corpus-based ideational metafunctional analysis of Pakistan Prime Minister Imran Khan's speech at United Nations general assembly. Cogent Social Sciences, 7(1). https://doi.org/10.1080/23311886.2020.1856999

Newman, J. (2008). Spoken corpora: Rationale and application. Taiwan Journal of Linguistics, 6(2), 27-58.

O'Keeffe, A., McCarthy, M., \& Carter, R. (2007). From corpus to classroom: Language use and language teaching. Cambridge University.

Özbay, A., \& Kayaoglu, M. N. (2015). EFL teacher's reflections towards the use of computerized corpora as a teaching tool in their classrooms. Cukurova University Faculty of Education Journal, 44(1). 85-104. https://dergipark.org.tr/en/pub/cuefd/article/54367

Reppen, R. (2011). Using corpora in the language classroom. In B.Tomlinson (Ed.), Materials 
Development in Language Teaching (second edn.). Cambridge University.

Reppen, R. (2010). Using Corpora in the Language Classroom. Cambridge University.

Rezaee, A. A., Marefat, H., \& Saeedakhtar, A. (2015). Symmetrical and asymmetrical scaffolding of L2 collocations in the context of concordancing. Computer Assisted Language Learning, 28(6), 532-549. https://doi.org/10.1080/09588221.2014.889712

Römer, U. (2006). Pedagogical applications of corpora: Some reflections on the current scope and a wish list for future developments. Zeitschrift für Anglistik und Amerikanistik, 54(2), 121-134. https://www.degruyter.com/document/doi/10.1515/zaa-2006-0204/html

Romer, Ute (2005). Progressives, Patterns, Pedagogy: A corpus-driven approach to English progressive forms, functions, contexts and didactics. John Benjamins

Sinclair J. (ed.) (2004). How to use corpora in language teaching. John Benjamins.

Smart, J. (2014). The role of guided induction in paper-based data-driven learning. ReCALL, 26(2), 184-201. https://www.cambridge.org/core/journals/recall/article/abs/role-of-guidedinduction-in-paperbased-datadrivenlearning/729C745E3D31FBB5067497A583366CE0

Stefanowitsch, A. (2020). Corpus linguistics: A guide to the methodology. Language Science. Timmis, I. (2015). Corpus linguistics for ELT: Research and Practice. Routledge.

Tono, Y., Satake, Y., \& Miura, A. (2014). The effects of using corpora on revision tasks in L2 writing with coded error feedback. ReCALL, 26(2), 147-162. https://www.cambridge.org/core/journals/recall/article/abs/effects-of-usingcorpora-on-revision-tasks-in-12-writing-with-coded-errorfeedback/3498F1000F12F48E24728B48AEABC1D4

Woods, D. (1996). Teacher cognition in language teaching: Beliefs, decision-making and classroom practice. Cambridge University.

Yang, B. (2016). A corpus-based comparative study of" Learn" and" Acquire". English Language Teaching, 9(1), 209-220. https://eric.ed.gov/?id=EJ1087079

Yoon, H., \& Hirvela, A. (2004). ESL student attitudes toward corpus use in L2 writing. Journal of Second Language Writing, 13(4), 257-283. https://doi.org/10.1016/j.jslw.2004.06.002

Yunus, K. (2017). Corpus Linguistics: Pedagogic application in the $21^{\text {st }}$ century. International Journal of Academic Research in Progressive Education and Development, 6(3), 137-152. http://dx.doi.org/10.6007/IJARPED/v6-i3/3167

Yusuf, K. (2020). Data driven learning by discovering lexical bundles using corpus resources. In International Conference on English Language Teaching (ICONELT 2019), 4750. Atlantis Press. file:///E:/IDEA\%20JOURNAL/125939256.pdf

Zahra, T., \& Abbas, A. (2018). Pedagogical implications of corpus-based approaches to ELT in Pakistan. Journal of Education and Educational Development, 5(2), 259-275. https://eric.ed.gov/?id=EJ1200277 